\title{
STRUCTURE OF SERVICE SECTOR OF GEORGIA
}

\section{MARIKA PIRVELI}

University of Szczecin, Faculty of Geosciences, POLAND

e-mail: mariam.pirveli@usz.edu.pl

RECEIVED
ACCEPTED
JEL
CLASSIFICATION

KEYWORDS

ABSTRACT
10 December 2018

28 December 2018

L8, R1

Georgia, GeoStat.Ge, services sector

In recent years, interest in Georgia has been growing. The country belongs to the Eastern Neighborhood area. Polish and international organizations systematically announce competitions, based on sharing experience and knowledge in the field of institutional and local government administration, education, science, business; most of international aid supports Georgia in the transformation process and helps to adapt the local soft and hard infrastructure to the requirements of the free market. Researchers, universities and business entities often are in need to get up to databases giving a picture of this country and region. The purpose of this text is to present the structure of the current statistical information regularly collected by the Georgia's statistical office (Geostat) and available in the digitized space. This review paper provides general information about Georgia, including a historical feature with an emphasis on the experience of creating databases. Next, it presents the structure of statistical data collected by the GeoStat.Ge, discussing in detail the services sector. Through the reviewed data structures, it draws attention to several properties, that result from the specificity of the Georgian national economy.

\section{Introduction}

Georgia is a small country, inhabited by different nationalities and belonging to different religions, most of which are Georgian. It's area is 69.700 sq.km and the population - 3,729.6 thousand persons (by January 1 , 
2018). ${ }^{1}$ Britannica describes Georgia as a country of Transcaucasia located at the eastern end of the Black Sea on the southern flanks of the main crest of the Greater Caucasus Mountains. It is bounded on the north and northeast by Russia, on the east and southeast by Azerbaijan, on the south by Armenia and Turkey, and on the west by the Black Sea. Georgia includes three ethnic enclaves: Abkhazia, Ajaria and South Ossetia. The capital of Georgia is Tbilisi.

The roots of the Georgian people extend deep in history; their cultural and urban heritage is equally ancient and rich. In Hellenistic times here was the area of Greek colonization, and later there was the province of the Roman Empire. This means that all institutions inseparably associated with Greek polis were represented in Hellenistic cities in Georgia (Pirveli, 2002). During the medieval period a powerful Georgian kingdom existed, reaching its height between the $10^{\text {th }}$ and $13^{\text {th }}$ centuries. According to the historical chronicles collection of statistical data started in here just in $13^{\text {th }}$ century. In the years of 1254-1258 Khan Arghun of Mongolia conducted the census of the population of Georgia and inventory of their assets (Chkhikvishvili, 1982, p. 72). Since 1689 chiefs of military-territorial units began conducting the population censuses in their regions once per seven years (Dzidziguri, Abashidze, Aleqsidze, 1985). The surviving books of XVII-XVIII cc. contain the data obtained from these censuses. After a long passé of Turkish and Persian domination, country was annexed by the Russian Empire in the $19^{\text {th }}$ century. On November 15, 1918 a temporary Bureau of Statistics was set up at the Ministry of Agriculture (Atanelishvili, 1994, p. 159). The functions of the Bureau included developing the materials for conducting an agricultural inventory, was recording the land bank and determining the norms for its distribution (Atanelishvili, 1994, p. 169). On July 25, 1919 under the Law adopted by the Constituent Assembly, the Central Statistical Committee of the Republic was set up at the Ministry of Agriculture. The Committee was tasked to manage all the statistical works of state significance. An independent Georgian state existed from 1918 to 1921, when it was incorporated into the Soviet Union. After the Soviet occupation, on April 3, 1921 the Revolutionary Committee issued the Decree on Establishing the Central Statistics Division of Soviet Republic of Georgia and on July 4, 1921 the first charter for the state statistical bodies of Georgia was published (News Archive, 2017). The seventy-year Sovietization ended in 1989, when the country declared sovereignty on November 19, 1989. It was the beginning of economic blockade and, in the same time, of profound changes aimed at building free market structures on the site of a centrally controlled economy. The period of economic blockage was reflected in the full disappearance of energy, water supply, heating, electricity, industry, services and jobs, giving the inhabitants basic living conditions (Strachota, 2007; Sadłocha, 2017). In addition, civil wars began, which did not favor changes in the political system and the economy (Dabrowski, 2004).

The number of Georgian population in the 1990-2018 period is characterized by decreasing trend. This is about the data released by Geostat, according to which the number of population reduced from 5,424,400 in 1990 to $3,729,600$ in 2018. During this period there was declined both, urban and rural areas residents. Residents of Tbilisi in 2018 (1,158,677 people), in comparison to 1989 (1,263,489 people), decreased by about 100,000 people, while in regions the decline exceeded $1,088,000$ people. In the same period increased urbanization rate percent from 53.8 percent to 58.3 percent. According to experts, the main reason for population reducing is increased mortality, birth rate and migration abroad (Shavishvili, Kavelashvili, 2018). Probably, the reason for the increased urbanization rate is not the urbanization but the depopulation of the village and the intensification of internal migrations from the countryside to the cities. The distribution of the population to urban centers in recent years, as the rural population

${ }^{1}$ As a result of the seizure of Abkhazia and South Ossetia by Russia, Georgia controls de facto 57,250 sq.km of its area. 
has decreased by about $1 / 4$ since the beginning of the $21^{\text {st }}$ century. More than half the population lives in cities. Further, a considerable portion of the population, that is defined as rural, is in fact engaged in the urban economy of nearby cities (more than $1 / 3$ de facto live in Tbilisi). Enterprises for primary processing of agricultural products have been constructed in the villages, while ore-processing plants and light industry also are increasing in number. Table 1 shows investment in fixed assets in enterprises of trade, repair of vehicles, personal and household goods by regions. The best turnover (not Tbilisi) is in the region Adjaria, Imereti and Sanegrelo, where light industry is developed. The number of rural inhabitants remains there as high as it is because of the wide distribution of laborintensive branches of the economy such as the tea and subtropical crop plantations.

Table 1. Investment in fixed assets in enterprises of trade, repair of vehicles, personal and household goods by regions

\begin{tabular}{|c|c|c|c|c|c|c|c|c|c|c|c|c|}
\hline \multirow{3}{*}{ Year } & \multirow[t]{2}{*}{ Georgia } & \multicolumn{11}{|c|}{ of which } \\
\hline & & Tbilisi & Adjara & Guria & Imereti & Kakheti & $\begin{array}{l}\text { Mtskheta- } \\
\text { Mtianeti }\end{array}$ & $\begin{array}{l}\text { Racha- } \\
\text { Lechkhumi } \\
\text { and Kvemo } \\
\text { Svaneti }\end{array}$ & $\begin{array}{c}\text { Samegrelo- } \\
\text { Zemo } \\
\text { Svaneti }\end{array}$ & $\begin{array}{l}\text { Samtskhe- } \\
\text { Javakheti }\end{array}$ & $\begin{array}{c}\text { Kvemo } \\
\text { Kartli }\end{array}$ & $\begin{array}{l}\text { Shida } \\
\text { Kartli }\end{array}$ \\
\hline & \multicolumn{12}{|c|}{$\mathrm{m} \ln \mathrm{GEL}$} \\
\hline 2006 & 146.0 & 124.8 & 5.5 & 0.3 & 2.2 & 2.0 & 3.6 & 0.0 & 4.7 & 0.3 & 1.4 & 1.2 \\
\hline 2007 & 202.7 & 178.5 & 8.2 & - & 6.5 & 0.4 & - & - & 6.3 & 0.3 & 1.6 & 0.9 \\
\hline 2008 & 241.5 & 222.3 & 5.3 & 0.3 & 4.2 & 1.5 & 0.0 & 0.0 & 4.9 & 0.3 & 2.1 & 0.6 \\
\hline 2009 & 260.4 & 247.6 & 2.2 & 0.1 & 3.6 & 2.2 & 0.0 & 0.0 & 1.3 & 0.8 & 1.2 & 1.4 \\
\hline 2010 & 501.9 & 489.3 & 3.9 & 0.1 & 2.4 & 0.8 & 0.3 & 0.0 & 1.3 & 1.1 & 1.3 & 1.4 \\
\hline 2011 & 273.9 & 251.8 & 10.4 & 0.1 & 3.5 & 1.4 & 0.0 & - & 1.0 & 2.3 & 1.7 & 1.6 \\
\hline 2012 & 234.8 & 192.3 & 14.1 & 0.1 & 6.1 & 0.7 & 7.0 & 0.0 & 1.0 & 5.4 & 5.2 & 3.0 \\
\hline 2013 & 453.6 & 388.8 & 25.6 & 0.3 & 5.4 & 9.6 & 2.0 & 0.0 & 5.1 & 2.0 & 2.8 & 11.9 \\
\hline 2014 & 425.5 & 371.3 & 17.5 & 1.1 & 8.3 & 6.0 & 1.3 & 0.0 & 6.5 & 2.0 & 8.4 & 3.0 \\
\hline 2015 & 595.6 & 541.7 & 27.1 & 0.5 & 6.2 & 3.0 & 0.7 & - & 2.0 & 1.0 & 8.8 & 4.7 \\
\hline 2016 & 417.6 & 348.6 & 23.5 & 0.7 & 10.0 & 8.4 & 1.8 & 0.2 & 8.4 & 3.3 & 8.5 & 4.3 \\
\hline 2017 & 634.2 & 560.3 & 43.1 & 0.3 & 12.9 & 2.1 & 1.4 & 0.0 & 1.0 & 1.2 & 9.4 & 2.5 \\
\hline
\end{tabular}

Source: GeoStat.Ge (2019e).

The great achievement of the transformation period is the fact, that the vast majority of jobs are produced in the non-state sector; even some branches of the national economy are fully located only on the private sector (e.g. hotel industry, etc.). Figure 1 shows the number of population and employment by institutional sectors (state and non-state sector). More than half of the population remains unemployed, however, the group of registered unemployed is small. The majority of employees are people working in the private sector (mostly self-employment). The lion's share of employees are over 35 ; however, there are some sections that have been fully rejuvenated and employ people under 35 (e.g. government administration). 


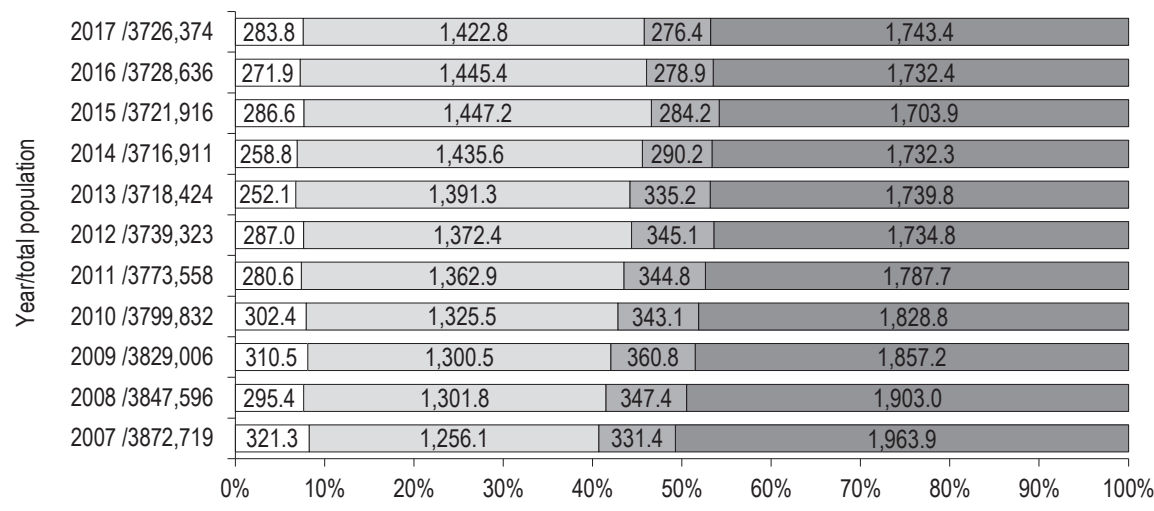

$\square$ State sector $\quad \square$ Non-State Sector $\quad \square$ Unemployment $\quad \square$ Rest Population

Figure 1. Number of population and employment by institutional sectors (data by January 1. Elaboration based on GeoStat.Ge) (in thousands)

Source: Integrated Household Survey (2016); Labour Force Survey (2017).

\section{GeoStat.Ge transforming activity}

After collapse of the Soviet Union, the need to make fundamental changes to all the tools and methods arose along with the need to identify different, alternative sources for obtaining the data. It became important to develop and introduce the indicators characteristic for a market economy. Since 11 December 2009 the Law of Georgia on Official Statistics provides a legal basis for its functioning; all statistical activities are carried out by an independent body of National Statistics Office of Georgia. Table 2 shows the most important legislative changes that have made the structural transformation of the current statistical office, that for 70 years was a typical Soviet office.

Table 2. Chronology of key legislative changes structuralizing the statistical office of Georgia After collapse of the Soviet Union in 1990s

\begin{tabular}{|c|c|}
\hline Date & Key legislative changes and international projects \\
\hline 1991-1995 & $\begin{array}{l}\text { According to the Law of Georgia, dd } 27 \text { February 1991, on the Structure and the Rules of Operations of the Executive Power, } \\
\text { the statistical activities in the country were carried out by the Social and Economic Information Committee established at the } \\
\text { Supreme Council of Georgia. }\end{array}$ \\
\hline 1995 & $\begin{array}{l}\text { By the Decision of the Cabinet of Ministers, dd } 3 \text { April 1995, was established the State Fund of Statistics Development in order } \\
\text { to support and further develop the facilities for carrying out statistical works. }\end{array}$ \\
\hline $1995-1997$ & $\begin{array}{l}\text { The State Department of Social and Economic Information carried out the statistical works according to the Law of Georgia, } \\
\text { dd } 8 \text { December 1995, on the Structure and the Rules of Operations of the Executive Power. }\end{array}$ \\
\hline $1996-1997$ & $\begin{array}{l}\text { At the Ordinance of the President of Georgia, from April } 1996 \text { to October } 1997 \text { the state temporary commission was set up in } \\
\text { order to further develop the state statistics. High officials representing the Ministry of Economics of Georgia, State Department } \\
\text { of Social and Economic Information, National Bank of Georgia, Ministry of Finance of Georgia and the State Chancellery served } \\
\text { on the Commission. }\end{array}$ \\
\hline $1997-2004$ & The State Department of Statistics of Georgia used to carry out the statistical activities. \\
\hline $1998-2009$ & The Law on Statistics, adopted in 1997, was applied. \\
\hline $2004-2009$ & $\begin{array}{l}\text { The Department of Statistics was merged with the Ministry of Economic Development of Georgia; all the statistical activities were } \\
\text { carried out as a subordinated body of the Ministry of Economic Development of Georgia. }\end{array}$ \\
\hline
\end{tabular}

Source: based on: GeoStat (2019a). 
GeoStat.Ge carries out its functions taking into account the international methodology and standards (Methodology, 2019). Georgian statistical office bases its methodology on the methodology provided by the European Communities, International Monetary Fund, Organisation for Economic Co-operation and Development, United Nations and World Bank (System of National Accounts 2008, 2009). They have been implemented mostly through 22 international projects; they are described in table 3 by duration, project title and financing organization (Table 3).

Table 3. Chronology of international projects structuralizing the statistical office of Georgia

\begin{tabular}{|c|c|}
\hline Duration & International projects (Donor organization) \\
\hline 1 V 2011-1 V 2014 & $\begin{array}{l}\text { Cooperation project between National Statistics of Georgia (Geostat) and Statistics Sweden (Donor: Sida. Statistics } \\
\text { Sweden). }\end{array}$ \\
\hline $10 \mid 2006-31$ XII 2013 & $\begin{array}{l}\text { Data collection and analyses project (under USDA Caucasus agricultural development initiative) (Donor: USDA - United } \\
\text { States Department of Agriculture). }\end{array}$ \\
\hline 1 | $2011-1$ V|| 2013 & $\begin{array}{l}\text { Bilateral cooperation project between Statistics Netherlands and National Statistics Office of Georgia (Donor: } \\
\text { The government of the Netherlands). }\end{array}$ \\
\hline 1 | $2011-1$ V|| 2013 & $\begin{array}{l}\text { Bilateral Cooperation Project between Armenia and Georgia within the framework of International Global Comparisons } \\
\text { Program by } 2011 \text { indicators (Donor: The World Bank). }\end{array}$ \\
\hline VII 2014-XII 2014 & $\begin{array}{l}\text { Support the development of the Georgian System of Statistics in the field of regional accounts. Transfer of knowledge } \\
\text { required to carry out calculations of selected macroeconomic categories by regions (Donor: Ministry of Foreign Affairs } \\
\text { of the Republic of Poland). }\end{array}$ \\
\hline 1 IX 2012-3 VI 2013 & Implementation of the Accelerated Data Program (ADP) in Georgia (Donor: OECD). \\
\hline 15 XI 2013-17 XI 2017 & $\begin{array}{l}\text { Global research on Child labor Measurment and Policy Development (MAP) (Donor: The United States Department } \\
\text { of Labor). }\end{array}$ \\
\hline $1 \mid 2011-31$ XII 2017 & $\begin{array}{l}\text { Support to improved data collection and analysis on population issues for integration of population. (Donor: Government } \\
\text { of Sweden (through Sida - Statistics Sweden), UNFPA). }\end{array}$ \\
\hline 24 IV $2017-30$ X 2017 & Energy consumption in households survey. (Donor: Energy Community Secretariat of Czech Republic) \\
\hline $2014-2015$ & $\begin{array}{l}\text { Support the development of the Georgian System of Statistics in the field of regional statistics (Implementing agency: } \\
\text { Central Statistics Office of Poland). }\end{array}$ \\
\hline 2 | 2015-31 X|| 2015 & $\begin{array}{l}\text { Support for the development of Georgian System of Statistics in the field of environment statistics (Implementing agency: } \\
\text { Central Statistical Office of Poland). }\end{array}$ \\
\hline 1 X 2013-30 IX 2017 & Georgian Agricultural Policy Initiative (Donor: USDA - United States Department of Agriculture). \\
\hline 1 III 2013-1 III 2016 & $\begin{array}{l}\text { European Neighbourhood Programme for Agriculture and Rural Development (ENPARD Georgia. Implementing agency: } \\
\text { FAO). }\end{array}$ \\
\hline 1 V 2015-30 VI 2018 & $\begin{array}{l}\text { Cooperation project between National Statistics Office of Georgia (Geostat) and Statistics Sweden (Donor: Sida. } \\
\text { Statistics Sweden). }\end{array}$ \\
\hline 5 | 2009-present & National Accounts Statistics Mission (Donor: IMF). \\
\hline 1 III 2017-31 III 2018 & National Survey on Violence Against women in Georgia (Donor: UN Women). \\
\hline 27 VII 2015-18 III 2018 & Statistical Capacity Development for Social Inclusion and Gender Equality (Donor: ADB). \\
\hline 10 | 2017-30 IX 2018 & $\begin{array}{l}\text { Data collection and analyses project (under USDA Caucasus agricultural development initiative) (Donor: USDA - United } \\
\text { States Department of Agriculture). }\end{array}$ \\
\hline 1 | 2017-31 ||| 2019 & Multiple Indicator Cluster Survey - 2018 Georgia MICS (Donor: UNICEF). \\
\hline 6 || 2017-31 ||| 2019 & $\begin{array}{l}\text { Provision of Statistical Services for Purchasing Power Parities (PPP) for Georgia and Ukraine (Donor: Eurostat (via ICON } \\
\text { institute). }\end{array}$ \\
\hline $2016-2020$ & $\begin{array}{l}\text { ENI SEIS II EAST - Implementation of the Principles and Practices of the Shared Environmental Information System } \\
\text { (SEIS) in the Eastern Partnership Countries Funded by European Neighbourhood Instrument (ENI) and Implemented } \\
\text { by the European Environment Agency. }\end{array}$ \\
\hline
\end{tabular}

Source: based on: GeoStat $(2019 b, c)$. 


\section{Organizational structure and main areas of statistical data}

The head of the statistical office is the Executive Director. The organizational structure consists of two Deputy Executive Director, Board, Advisory Board and 11 departments organized in three sectors, divided into 34 branches. They are:

I. Executive Director, together with the Deputies, Board and Advisory Board manage:

1. Department of Strategic Planning, Coordination and Communication (with five branches),

2. Information Technology Department (with two branches),

3. International Audit Department.

II. One of the Deputy Executive Director supervises the work of the:

4. Social Statistics Department (with three branches),

5. Price Statistics Departments (with two branches),

6. National Accounts Department (with two branches),

7. External Trade and Foreign Investments Statistics Department (with two branches).

III. Another Deputy Executive Director conducts:

8. Population Census and Demographic Statistics Department,

9. Agricultural and Environmental Statistics Department (with two branches),

10. Business Statistics Department (with five branches),

11. Regional Offices (with eleven branches).

Collected and compiled by 11 departments (34 branches) statistical information is published in the form of 23 blocks, called Main Statistics (Table 4).

Table 4. Structure of Main Statistics GeoStat.Ge

\begin{tabular}{|c|c|}
\hline Main Statistics & Statistical information \\
\hline 1 & 2 \\
\hline $\begin{array}{l}\text { GDP and Other Indicators } \\
\text { of National Accounts }\end{array}$ & $\begin{array}{l}\text { Gross Domestic Product (GDP). Supply and use tables. Gross National Income (GNI). GDP Calculation Methodology. } \\
\text { Publications (Quarterly). Publications (Annual) }\end{array}$ \\
\hline Price Indices & $\begin{array}{l}\text { Consumer Price Index (Inflation). Producer and Import Price Indices. Inflation Calculation Methodology. Publications } \\
\text { (Monthly) }\end{array}$ \\
\hline External Trade & $\begin{array}{l}\text { Georgian exports by countries. Georgian exports by country groups. Georgian exports by commodity groups } \\
\text { (HS } 4 \text { digit level). Georgian exports by commodity groups (HS } 6 \text { digit level). Export of major commodity groups. } \\
\text { Georgian Exports by BEC (Broad Economic Categories). Georgian Exports by SITC section. Exports of Georgia by } \\
\text { mode of transport. Exports of Georgia by kind of economic activities (NACE Rev.2). Exports of Georgia by size of the } \\
\text { Trader's subject. Georgian Imports by countries. Georgian imports by country groups. Georgian imports by commodity } \\
\text { groups (HS } 4 \text { digit level). Georgian imports by commodity groups (HS } 6 \text { digit level). Import of major commodity groups. } \\
\text { Georgian imports by BEC (Broad Economic Categories). Georgian imports by SITC section. Imports of Georgia by } \\
\text { mode of transport. Imports of Georgia by kind of economic activities (NACE Rev.2). Imports of Georgia by size of the } \\
\text { Trader's subject. Exports and imports of Georgia by months }\end{array}$ \\
\hline Foreign Direct Investments & $\begin{array}{l}\text { Foreign Direct Investments by Countries. Foreign Direct Investments by Economic Sectors. Foreign Direct } \\
\text { Investments by Information Sources. Foreign Direct Investments by Regions. Foreign Direct Investments in Georgia } \\
\text { by Components. Foreign Direct Investments in Georgia for 1996-2018. Foreign Direct Investments Position } \\
\text { (Integrated format). For more details see the web site of National Bank }\end{array}$ \\
\hline Employment and Wages & Employment and Unemployment. Labour Force Statistics. Wages. Publications (Annual) \\
\hline Population & $\begin{array}{l}\text { Population. Birth. Deaths. Natural Increase. Migration. Marriages. Divorces. Summary vital statistics, January-June } \\
2018 \text { (Preliminary Data). Annual Publications }\end{array}$ \\
\hline
\end{tabular}




\begin{tabular}{|c|c|}
\hline 1 & 2 \\
\hline $\begin{array}{l}\text { Standard of Living, } \\
\text { Subsistence Minimum }\end{array}$ & $\begin{array}{l}\text { Subsistence Minimum. Subsistence Minimum Calculation Methodology for Working Age Male. Incomes of Household. } \\
\text { Expenditures of Household. Poverty Indicators. Publications (Annual) }\end{array}$ \\
\hline Justice Statistics & Criminal Justice Statistics. Administrative Violations \\
\hline $\begin{array}{l}\text { Healthcare and Social } \\
\text { Protection }\end{array}$ & Healthcare. Social protection \\
\hline Education and Culture & Education. Culture \\
\hline Business Statistics & $\begin{array}{l}\text { Turnover. Production value. Number of persons employed. Number of employees. Average monthly remuneration } \\
\text { of employed persons. Value added. Intermediate consumption. Personnel costs. Total purchases of goods and } \\
\text { services. Purchases of goods and services for resale. Investment in fixed assets. Methodology for Calculation of Key } \\
\text { Indicators of Business Statistics }\end{array}$ \\
\hline Business Register & $\begin{array}{l}\text { By kind of economic activity. By ownership type. By legal status. By regions } \\
\text { Business demography indicators }\end{array}$ \\
\hline $\begin{array}{l}\text { Agriculture, Environment } \\
\text { and Food Security }\end{array}$ & $\begin{array}{l}\text { Agriculture. Food Security. Environment } \\
\text { Publications (Annual) }\end{array}$ \\
\hline $\begin{array}{l}\text { Industry, Construction } \\
\text { and Energy Statistics }\end{array}$ & Industry. Construction. Energy Statistics \\
\hline Service Statistics & $\begin{array}{l}\text { Trade. Hotels and Restaurants. Transport. Other Service Statistics. Activities of Economic Agents Engaged } \\
\text { in Organization of Markets (2017) }\end{array}$ \\
\hline $\begin{array}{l}\text { Government Finance } \\
\text { Statistics }\end{array}$ & General Government budget. Central Government budget. For more details see the web site of Ministry of Finance \\
\hline Monetary Statistics & $\begin{array}{l}\text { Money supply by aggregates. Structure of Domestic credits. Deposits. Exchange rates. Pawnshop survey results. } \\
\text { For more details see the web site of National Bank }\end{array}$ \\
\hline IMF SDDS & $\begin{array}{l}\text { International Monetary Data. Advance Release Calendar. National Summary Data Page. IMF Dissemination Standards } \\
\text { Bulletin Board (DSBB) }\end{array}$ \\
\hline Gender Statistics & Women and men in Georgia, 2017, 2015, 2013, 2011 \\
\hline Regional Statistics & $\begin{array}{l}\text { Regional Statistics. Population. Economic Activity. Business Sector. Industry. Construction. Service Areas. Standard } \\
\text { of Living. Health Care and Social Protection. Education. Culture. Infrastructure. Agriculture. Environment. Foreign } \\
\text { Direct Investments. Gross Domestic Product }\end{array}$ \\
\hline Tourism Statistics & Domestic Tourism. Inbound Tourism \\
\hline $\begin{array}{l}\text { Information and } \\
\text { Communication Technology } \\
\text { (ICT) and Innovations }\end{array}$ & $\begin{array}{l}\text { Information and Communication Technologies } \\
\text { Innovation Activity of Enterprises (2013-2015, aggregated) } \\
\text { Innovation Activity of Enterprises }\end{array}$ \\
\hline
\end{tabular}

Source: GeoStat (2019d).

On the office's website (www.geostat.ge) also other information is available in applications like: Database, Publications, Products, Methodology, Meta-Data. (Other icons - About Us, Calendar, Links, Service and fees - are of organizational nature). For example: under the icon Publications are issued:

- Quarterly Bulletin (from 4Q-2015 - present),

- Gross Domestic Product of Georgia (from 2016 - present),

- Foreign Direct Investments (from 4Q-2016 - present),

- Small and Medium Business in Georgia (2009),

- Agriculture of Georgia (from 2012 - present),

- Producer Price Index in Georgia (2018).

Transformation and fundamental restructuring of the Economy and of the Geostat (the institution, which documents the condition, resources, values and potential of the whole state and its regions) is continued and is in the process. But one can already notice, that National Economy, once dominated by the state sector, explicitly changes its structure and strongly arrives examples of self-employment (Figure 1). 


\section{Structure of Sepvice statistics}

Under the service statistics are treated: Trade, Hotels and Restaurants, Transport, Other Service Statistics, Activities of Economic Agents Engaged in Organization of Markets. They are all described according to a common formula. In few cases, the formula is a supplement in the form appropriate for a given form of information.

Table 5. Data structure of the site Service Statistics

\begin{tabular}{|c|c|c|c|}
\hline Service statistics & Table of Contents & $\begin{array}{l}\text { Each entry in the Table of Contents is } \\
\text { described by: }\end{array}$ & Download statistics for each entry \\
\hline 1 & 2 & 3 & 4 \\
\hline Trade & $\begin{array}{l}\text { - trade, repair of vehicles, } \\
\text { personal \& household goods } \\
\text { by classification of economic } \\
\text { activity NACE rev.1.1, } \\
\text { - wholesale and retail trade, } \\
\text { repair of motor vehicles and } \\
\text { motorcycles by classification } \\
\text { of economic activity NACE } \\
\text { rev.2 }\end{array}$ & $\begin{array}{l}\text { - turnover, } \\
\text { - production value, } \\
\text { - number of persons employed, } \\
\text { - number of employees, } \\
\text { - average monthly remuneration of employed } \\
\text { persons, } \\
\text { - value added, } \\
\text { - intermediate consumption, } \\
\text { - personnel costs, } \\
\text { - total purchases of goods and services, } \\
\text { - purchases of goods and services for resale, } \\
\text { - investment in fixed assets }\end{array}$ & $\begin{array}{l}\text { - by size of enterprises according to the old } \\
\text { methodology, } \\
\text { - by size of enterprises according to the new } \\
\text { methodology, } \\
\text { - by kind of economic activity, } \\
\text { - by ownership type, } \\
\text { - by organizational legal forms, } \\
\text { - by regions }\end{array}$ \\
\hline \multirow[t]{2}{*}{$\begin{array}{l}\text { hotels and } \\
\text { Restaurants }\end{array}$} & $\begin{array}{l}\text { - hotels and restaurants by } \\
\text { classification of economic } \\
\text { activity NACE rev.1.1, } \\
\text { - accommodation and } \\
\text { Food Service Activities by } \\
\text { classification of economic } \\
\text { activity NACE rev.2 }\end{array}$ & as above & as above \\
\hline & $\begin{array}{c}\text { - information on hotels and } \\
\text { Hotel Type Enterprises) }\end{array}$ & unnecessary cell & $\begin{array}{l}\text { - number of visitors in hotels and hotel } \\
\text { type enterprises by country and purpose } \\
\text { of arrival in 2017, } \\
\text { - main indicators of hotels and hotel type } \\
\text { enterprises (2017) }\end{array}$ \\
\hline Transport & $\begin{array}{l}\text { - transportation and } \\
\text { communication by } \\
\text { classification of economic } \\
\text { activity NACE rev.1.1, } \\
\text { - transportation and storage } \\
\text { by classification of economic } \\
\text { activity NACE rev.2 }\end{array}$ & $\begin{array}{l}\text { - turnover, } \\
\text { - production value, } \\
\text { - number of persons employed, } \\
\text { - number of employees, } \\
\text { - average monthly remuneration of employed } \\
\text { persons, } \\
\text { - value added, } \\
\text { - intermediate consumption, } \\
\text { - personnel costs, } \\
\text { - total purchases of goods and services, } \\
\text { - purchases of goods and services for resale, } \\
\text { - investment in fixed assets }\end{array}$ & $\begin{array}{l}\text { - by size of enterprises according to the old } \\
\text { methodology, } \\
\text { - by size of enterprises according to the new } \\
\text { methodology, } \\
\text { - by kind of economic activity, } \\
\text { - by ownership type, } \\
\text { - by organizational legal forms, } \\
\text { - by regions }\end{array}$ \\
\hline
\end{tabular}




\begin{tabular}{|c|c|c|c|}
\hline 1 & 2 & 3 & 4 \\
\hline \multirow[t]{2}{*}{$\begin{array}{l}\text { Other Service } \\
\text { Statistics }\end{array}$} & $\begin{array}{l}\text { - other Service Statistics } \\
\text { Section by classification } \\
\text { of economic activities NACE } \\
\text { rev } 1.1\end{array}$ & $\begin{array}{l}\text { - real estate, renting and business activity, } \\
\text { - community, social and personal service } \\
\text { activities, } \\
\text { - education, } \\
\text { - health and social work }\end{array}$ & - remark (text description) \\
\hline & $\begin{array}{l}\text { - other Service Statistics } \\
\text { Section by classification } \\
\text { of economic activities NACE } \\
\text { rev.2) }\end{array}$ & $\begin{array}{l}\text { - real estate activities, } \\
\text { - professional, scientific and technical } \\
\text { activities, } \\
\text { - administrative and support service activities, } \\
\text { - education, } \\
\text { - human health and social work activities, } \\
\text { - information and communication, } \\
\text { - arts, entertainment and recreation, } \\
\text { - other service activities }\end{array}$ & as above \\
\hline $\begin{array}{l}\text { Activities } \\
\text { of Economic } \\
\text { Agents Engaged } \\
\text { in Organization } \\
\text { of Markets }\end{array}$ & unnecessary cell & unnecessary cell & $\begin{array}{l}\text { - number of markets and fairs by } \\
\text { organizational legal forms in Georgia, } \\
\text { - number of markets and fairs by ownership } \\
\text { type in Georgia, } \\
\text { - number of markets and fairs by type in } \\
\text { Georgia, } \\
\text { - number of markets and fairs on days } \\
\text { of trade, } \\
\text { - average annual number of employed } \\
\text { persons, } \\
\text { - financial indices of markets and fairs, } \\
\text { - number of market-place and sellers on the } \\
\text { markets and fairs). They are all described } \\
\text { according to a common formula. in some } \\
\text { cases, the pattern is complement in the } \\
\text { form relevant to the forms of information }\end{array}$ \\
\hline
\end{tabular}

Source: http://geostat.ge/index.php?action=page\&p_id=299\&lang=eng.

\section{Conclusions}

For Georgia November 19, 1989 was end of the seventy-year Sovietization and the beginning of economic blockade and, in the same time, of fundamental changes aimed at building free market structures on the site of a centrally controlled economy. Paradoxically, the most painful for Georgian society reality, turned out to be the simplest way to overcome the Soviet economy. The author has in mind the economic blockade imposed by Moscow as a punishment for the exodus from the soviet union. Full disappearance of workplaces in industry and lake of energy, water supply, heating, electricity, services and jobs started a long dark era and reduced the number of inhabitants by half; but also collapse of economy initiated the process, when employment and activity in the private sector dominates the public.

Still ongoing political transformation is supported by the international society and international organizations from Sweden, Norway, USA, Poland, Czech Republic, England, Netherlands (see Table 3). Information available on the website of Geostat is very different from the Soviet office, but many things still have to be fixed. The best evidence of the progress of changes, availability and quality of service is the fact that Georgia is recognized as a leader 
of liberal economic reforms in the South Caucasus region. The regulatory system offers favorable conditions for running a business, which is confirmed annually by high quotations in Doing Business ranking (9 $9^{\text {th }}$ place in the Doing business 2018 report). "Georgia is the only lower-middle-income one on the list [tab.6]. To date, no low-income economy has reached the top 20 group. [...] Having few bureaucratic hurdles, robust legal institutions and laws and regulations that are based on international good practices is what matters most for a good performance in the ease of doing business ranking. [...] Georgia, with a ranking of 9 , has implemented the highest number of business regulation reforms since the launch of Doing Business in 2003 - a total of 47." (Doing business, 2018, p. 3).

Table $\mathfrak{b}$. Ease of doing business ranking

\begin{tabular}{cccc}
\hline DB 2018 Rank & Economy & DFT score & DFT change \\
\hline 1 & New Zealand & 86.55 & -0.18 \\
2 & Singapore & 84.57 & +0.04 \\
3 & Denmark & 84.06 & -0.01 \\
4 & Korea, Rep & 83.92 & 0.00 \\
5 & Hong Kong SAR, China & 83.44 & +0.29 \\
6 & United States & 82.54 & -0.01 \\
7 & United Kingdom & 82.22 & -0.12 \\
8 & Norway & 82.16 & -0.25 \\
9 & Georgia & 82.04 & +2.12 \\
10 & Sweden & 81.27 & +0.03 \\
{$[\ldots]$} & {$[\ldots]$} & {$[\ldots]$} & {$[\ldots]$} \\
190 & Somalia & 19.98 & -0.31 \\
\hline
\end{tabular}

Source: Doing business (2018), p. 4.

\section{References}

Atanelishvili, T. (1994). Economic Reforms in the Democratic Republic of Georgia (1918-1921). Dissertation. Tbilisi: Tbilisi State University Press.

Chkhikvishvili, D. (1982). Ivane Javakhishvili - The works in twelve volumes. Volume III. Tbilisi: Tbilisi State University Press.

Dąbrowski, K. (2004). Etapy rozwoju gospodarczego Gruzji w latach 1801-2004. Międzywydziałowe Indywidualne Studia MatematycznoPrzyrodnicze. Warszawa: Uniwersytet Warszawski. Retrieved from: www.kaukaz.pl/pdf/t_historia_gospodarki_gruzji.pdf.

Doing Business (2018). A World Bank Group Flagship Report. Reforming to Create Jobs. Washington: WB. Retrieved from: www. doingbusiness.org/content/dam/doingBusiness/media/Annual-Reports/English/DB2018-Full-Report.pdf.

Dzidziguri, Sh. Abashidze, M. Aleqsidze, Z. (1985). De Grailly de Fois. De Grailly de Fois sur Georgie. In: Information about Georgia. Tbilisi: Publishing science.

GeoStat. (2019a). History. Retrieved from: www.geostat.ge/index.php?action=page\&p_id=29\&lang=eng.

GeoStat. (2019b). Ongoing international projects. Retrieved from: www.geostat.ge/index.php?action=page\&p_id=1235\&lang=eng.

GeoStat. (2019c). Completed international projects. Retrieved from: www.geostat.ge/index.php?action=page\&p_id=1916\&lang=eng.

GeoStat. (2019d). Main Statistics. Retrieved from: www.geostat.ge/index.php?action=page\&p_id=299\&lang=eng.

GeoStat. (2019e). Trade. Retrieved from: http://geostat.ge/index.php?action=page\&p_id=302\&lang=eng.

http://geostat.ge/index.php?action=page\&p_id=299\&lang=eng. 
Integrated Household Survey (2016). Retrieved from: www.ilo.org/dyn/lfsurvey/lfsurvey.list?p_lang=en.

Labour Force Survey (2017). Retrieved from: www.ilo.org/dyn/lfsurvey/lfsurvey.list?p_lang=en.

Methodology (2019). Retrieved from: www.geostat.ge/index.php?action=page\&p_id=14\&lang=eng.

News Archive (2017). National Statistics Office of Georgia celebrates the $98^{\text {th }}$ anniversary. Tbilisi: GeoStat.Ge. Retrieved from: www. geostat.ge/?action=news\&lang=eng\&npid=1166.

Pirveli, M. (2002). Miasto Gruzińskie w świetle europejskiej i orientalnej koncepcji urbanistycznej. Warszawa: Dialog.

Sadłocha, J. (2017). Rosyjska polityka wobec Gruzji. Retrieved from: www.psz.pl/117-polityka/jaroslaw-sadlocha-rosyjskapolityka-wobec-gruzji.

Shavishvili, P. Kavelashvili, M. (2018). Recalculation of basic demographic data of 1994-2014. Retrieved from:http://geostat.ge/cms/ site_images/files/georgian/population/gadaangarisheba\%20report\%20_\%20Geo_2018.pdf.

Strachota, K. (2007). Kryzys gruzińsko-rosyjski, Komentarz OSW. Retrieved from: http://osw.waw.pl/pub/koment/2006/10/061005.htm.

System of National Accounts 2008 (2009). New York: European Communities, International Monetary Fund, Organisation for Economic Co-operation and Development, United Nations and World Bank. Retrieved from: https://unstats.un.org/unsd/nationalaccount/ docs/sna2008.pdf.

Cite this article aS: Pirveli, M. (2018). Structure of service sector of Georgia. European Journal of Service Management, 4 (28/2), 327-337. DOI: 10.18276/ejsm.2018.28/2-39. 